Jurnal Kejuruteraan 30(2) 2018: 153-160

http://dx.doi.org/10.17576/jkukm-2018-30(2)

\title{
Cities Insane
}

\begin{abstract}
Bashir Olufemi Odufuwa*, Nathaniel Oluwaseun Ogunseye, Umar Obafemi Salisu \& Simeon Oluwagbenga Fasina Department of Urban and Regional Planning, Olabisi Onabanjo University, Nigeria
\end{abstract}

\begin{abstract}
Globally, cities are known to be the engines of development. Meanwhile, the failure of most Nigerian cities to satisfy the needs of city dwellers has increasingly become an issue of discourse in recent times. These inadequacies have been blamed on the unguided urbanization rate in most developing countries. Population increases and poor governance in most SubSaharan African cities are responsible for the increasing demands for social and economic services which invariably affect the level of satisfaction of city residents. This situation has partly necessitated the global urban campaign for liveable cities. This study assessed the satisfaction of residents in five Nigerian cities using a questionnaire survey. Stratified and random sampling methods were used to select 765 respondents so as to elicit information on city-living. The variables that determined the satisfaction of city residents were identified. Most of the respondents (82\%) were not satisfied with the cities due to the inadequate electricity/power supply, water, sanitation, transport, security, and health services in the cities. A chisquare analysis showed that the calculated values for the satisfaction with regard to selected variables of electricity supply [7.314]; transport [9.737]; recreation [12.024]; health [9.737]; telecommunication [21.291]; waste management [18.604] and water supply [23.988] in cities were less than the table value (31.41) at an alpha level of 0.05. This implied that there was no significant difference in the level of satisfaction. A factor analysis revealed the major determinants - reliable power supply, improved transport and water supply, employment opportunities, good medical services, enhanced food security that can improve the level of satisfaction with cities. Based on the findings, the implications of poorly serviced and managed cities on residents and national development were discussed.
\end{abstract}

Keywords: Cities; satisfaction; governance; insane; urban management

INTRODUCTION

Natural population dynamics and high rate of population increase in most Nigerian cities have become an issue of concern to city governance. In 1921, the country population was 18.63 million, and this rose to 30.4 million in 1952 . A drastic increase was experienced between 1963 (55.67 million) and 1991 (88.5 million). By 1996, the number of people increased to 104 million, while the most recent population census figure of 2006 reveals that population of the country was 140 million (National Population Commission (NPC), 2006). High population increase in cities and persistent rapid rural-urban migration are the resultant effects of natural population increase in the country (Agbola \& Agunbiade 2007; Egunjobi 1999). For instance, $7.2 \%$ of the country total population lived in cities of at least 20,000 people in 1921 . By 1952, 3.24 million people lived in 56 cities, representing about $10 \%$ of the total population (Oyesiku 2010). In 1963, 1990 and 1993, the proportion of city dwellers rose to $19.2 \%$, 20\% and 38\% respectively (Egunjobi 1999; Onibokun 1992; World Bank 1995). Globally, cities are noted as engine of development of any nation; indeed, failure of most cities, particularly in developing countries to measure up with this global recognition has led to unsatisfactory livelihoods of most cities dwellers (Agbola \& Agunbiade 2007). Similarly, increasing rate of urbanization problems in most developing countries, particularly cities is partly responsible for the recent world urban campaign for livable cities. Global population increase and ill-governance in Sub-Saharan African cities are responsible for increase in demands for social and economic services; which invariably affects residents' level of city satisfaction (Cohen 2004; Coker et al. 2007).

Cities, account for about $80 \%$ of the gross national product of developing countries, and produce capital, labour and markets for entrepreneurs for different economic activities (United Nations Development Programme (UNDP), 1996). Sequel to this assertion, city planning and development studies have being increasingly worried with realities of cities standing as backbone of development in developing countries. Indeed, if cities are engine that propel development and enhance quality of lives of most dwellers as obtains in industrialized countries; that ought to be the same in developing countries. Thus, city satisfaction lies heavily within the realm of efficient social and economic infrastructure. Studies revealed that situation of Nigeria cities is not only different, but displeasing (Adeagbo 2002; Odufuwa et al. 2009; Oyesiku, 1998 \& 2010). Generally, persistent increase in city population and attendant growth in economic activities have always being attributed with an array of consequences (Banister \& Bowling 2004; Ismail \& 
Hashim 2015). The intensity, dimension and ability to manage these consequences differ between developed and developing countries. In Nigeria, city dwellers are faced with different challenges that make cities a glowing hell on earth, creating increasing economic, social, security unrest and some other hearth disturbing issues leading to unsatisfactory living in cities. This paper examines city residents' satisfaction and implications on creating sustainable cities in Nigeria. The study identified factors that determine and influence residents' city satisfaction. Observed differences in city satisfaction among city residents in Nigeria, a situation that can propel crisis in cities was discussed. The implication of this situation on articulation of effective strategies for satisfactory living and city governance were discussed.

\section{CITIES AS CATALYST OF DEVELOPMENT: A BRIEF} LITERATURE REVIEW

Cities as mouth piece of any nation are places where people converge to interact, engage each other towards adding value to individuals and the nation at large. Literatures have demonstrated that cities are "drivers" of societal development, not simply bricks or mortar; they are usually places of dreams, nostalgia and imaginations. UN-HABITAT (2012) pointed to the fact that cities are places where people converge to actualize dreams, wishes and access knowledge that transform lives generally. Cities are noted to be locales of sufficiency that gives human beings required satisfactions of needs and services. It is pertinent to note that, location, historical details; prominent city characteristics are related with the extent and developmental pattern of any nation, Nigeria inclusive. These factors have contributed to cities becoming primary social, economic and political life-wire of most countries. Ariyo \& Jerome (2004) noted that ensuring an improved living standard of citizens is expected to be the aim of government. This implies that the performance of cities as engine of development in any nation is a major role of governments at all levels. Development revolves around effective infrastructure that can guarantee functional economic and enhances quality of life of residents.

Engelke (2012) reiterated that cities will increasingly shape social, political, economic and environmental conditions everywhere on earth. It was further noted that, cities draw natural resources from hinterlands for different manufacturing and economic development activities. This function will contribute to an enhance productivity and economic status of individuals and the country as a whole. While examining the impact of urbanization on city development, study emphasized that on the long run, urbanization could turn out to be positive or negative to human being and the environment (Engelke 2012). It was, however, mentioned that cities play pivotal role of housing political institutions, citadel of learning and industries. Thus, serves as engines of economic growth and dynamism, of learning and innovation, and of social and political life. For instance, about 90 prominent urban economies in China account for more than US\$6 trillion Gross Domestic Product
(GDP) of the country (McKinsey Global Institute 2010). Similarly, cities in India play host to about a third of the population, they however generate more than two-thirds of GDP, contributes about $90 \%$ of national tax revenues, and facilitate large number of employment (McKinsey Global Institute 2010). The increasing population and economic interactions in most cities propel the rising productivity level. This fact is connected to the state of city management or governance. An efficient city governance according to Glaeser (2011); Rosenthal \& Strange (2003) gives avenue to vibrant city competitiveness for innovations in production activities in particular.

Adeagbo (2002) explained that Nigerian cities, especially Lagos, Kano and Ibadan have witnessed rapid population and economic growth. Though this ought to be an opportunity for national development, but rather has unpleasant effects on cities life. The consequences of this on the image and viability of cities include housing shortage, inadequate and poor infrastructure, increasing crime rate, inadequate employment opportunity and vigorous environmental hazards. Instead of being engines of development, the adverse consequences are becoming embarrassing and displeasing to city residents, disturbing and distracting foreigners, particularly investors, rapidly frustrating professionals and worrisome to policy makers.

Based on the observed and fast approaching comatose situation of Nigerian cities as evident in incapacities of government to solely perform necessary live sustaining functions, the National Urban Development Policy (NUDP) was formulated. The rationale for this policy, based on the goal and objectives, is to enhance the management of Nigerian metropolitan centres and make them more efficient economically and socially as centres of commerce, industries, culture and the delivery of services to citizens towards improving their livability and making daily activities of residents less stressful. The recent clamor for smart cities globally calls for public attention to upheavals in Nigerian cities, particularly in the economic recession period. Thus, the issue of residents' satisfaction of cities is pertinent for overall justification for re-tooling city governance and regional or rural development in Nigeria.

\section{METHODOLOGY}

Based on commercial, administrative, political, population heterogeneity, brand names and historical factors, five Nigerian cities (Abuja - Centre of Unity; Benin City - Heart Beat of Nigeria; Lagos - Centre of Excellence; Kano - Centre of Commerce and Onitsha - Home for All) were chosen for this study. Selection of these cities was basically purposive and efforts were made to ensure regional representation of Nigerian cities. The study was conducted between July 2016 and October 2017. It focused on unveiling level of city residents' satisfaction with city lives and identifying various coping strategies in cities. The title "Cities Insane" was conceptualized based on the observed incompetency of most Nigerian cities to perform the globally expected roles 
of cities. It investigates why large numbers of people are vigorously interested in staying in cities despite high level of irresponsibility of most cities. This study is necessary for a better understanding of cities challenges and towards retooling developmental policy that will not only make cities viable, but which will reduce rural-urban and urban-urban migration, as well as foster regional or rural development in the country.

Though secondary data was used to buttress certain issues relating with city lives, through open and closed ended questionnaire survey, primary information were elicited from randomly selected 765 residents in different residential areas (high, medium and low density) of selected cities. Respondents were asked to rate the level of satisfaction with cities using a six point Likert scale (1- neutral, 2- very poor, 3- poor, 4-fair, 5- good and 6- very good). Apart from socio-economic information of cities residents, details of respondents' length of stay, purpose of stay or coming to city, cost of living, and determinants of stay among others were collected. Factor analysis was used to determine notable factors affecting city satisfaction. This method helps to reduce number of variables into manageable sizes for easy description (Oyesiku 1998) and generates factor values or loadings that were used to explain factors affecting city satisfaction. City satisfaction differences were analyzed and discussed.

\section{RESULTS AND DISCUSSION}

The socio-economic profile of respondents (Table 1) reveals that out of 765 respondents, $505(66 \%)$ were male while only $260(34 \%)$ were female. Since the study is not gender specific, the result can be said to be fairly gender balance. It can be inferred from this finding that living in cities is not exclusively a privy of men, but that women are also active city dwellers. The mean age of respondents is 34 years old; this gives an impression that all the respondents sampled were mature and can clearly express their feelings with regards to the scope of the study. There are few $100(13 \%)$ that are not educated; this indicates that most respondents possess at least basic education required to give their perspectives on city satisfaction. Also, most respondents 546 (71\%) were married, 466 (61\%) are self-employed and about $43(6 \%)$ are unemployed. It is obvious based on the results that cities contain people of various status and most are self-employed. This is not far-fetched, since selected cities are unarguably commercial centres that provide opportunities for people with entrepreneurial skills to get engaged. There are those engaged by the government (33\%), which is explained by the fact that selected cities are capital (administrative headquarters) of states except FCT Abuja, which is the capital of Nigeria. It is pertinent to note that, over time, cities have been increasingly experiencing high under employment opportunities and unequal income distribution among inhabitants.

This is a disturbing challenge affecting the welfare of individual and threatening the economic and social wellbeing of Nigerian cities. It affect most city dwellers in terms of difficulties faced by low income city dwellers in getting suitable job that is equivalent with acquired skills or qualifications, and uncertainty about their future income. It is interesting to note that low and unskilled workers continue to be on the increase, while the white-collar jobs are increasingly difficult to find in most cities. The reason for this is partly the failure of cities economy to generate enough employment opportunities for skilled and educated dwellers.

TABLE 1. Socio-economic profile of respondents

\begin{tabular}{|c|c|c|c|c|c|c|c|c|c|c|c|c|c|}
\hline \multirow{2}{*}{ Parameters } & & \multicolumn{2}{|c|}{ Abuja } & \multicolumn{2}{|c|}{ Benin } & \multicolumn{2}{|c|}{ Lagos } & \multicolumn{2}{|c|}{ Kano } & \multicolumn{2}{|c|}{ Onitsha } & \multicolumn{2}{|c|}{ Total } \\
\hline & & $\mathrm{N}$ & $\%$ & $\mathrm{~N}$ & $\%$ & $\mathrm{~N}$ & $\%$ & $\mathrm{~N}$ & $\%$ & $\mathrm{~N}$ & $\%$ & $\mathrm{~N}$ & $\%$ \\
\hline \multirow[t]{2}{*}{ Gender } & Male & 97 & 63.4 & 82 & 53.6 & 105 & 68.6 & 129 & 84.3 & 92 & 60.1 & 505 & 66.0 \\
\hline & Female & 56 & 36.6 & 71 & 46.4 & 48 & 31.4 & 24 & 15.7 & 61 & 39.9 & 260 & 34.0 \\
\hline Age (Mean) & & 38.7 & & 43.1 & & 42.5 & & 31.6 & & 40.3 & & - & - \\
\hline \multirow[t]{3}{*}{ Marital Status } & Married & 103 & 67.3 & 92 & 60.1 & 117 & 76.5 & 136 & 88.9 & 98 & 64.1 & 546 & 71.4 \\
\hline & Single & 41 & 26.8 & 59 & 38.6 & 31 & 20.3 & 17 & 11.1 & 49 & 32.0 & 197 & 25.8 \\
\hline & Divorce & 09 & 05.9 & 02 & 01.3 & 05 & 03.2 & - & - & 06 & 03.9 & 22 & 02.8 \\
\hline \multirow[t]{4}{*}{ Education } & No Education & 13 & 08.5 & 09 & 05.9 & 27 & 17.6 & 43 & 28.1 & 08 & 05.2 & 100 & 13.1 \\
\hline & Primary & 28 & 18.3 & 11 & 07.2 & 23 & 15.0 & 42 & 27.5 & 37 & 24.2 & 141 & 18.4 \\
\hline & Secondary & 71 & 46.4 & 58 & 37.9 & 49 & 32.0 & 51 & 33.3 & 65 & 42.5 & 294 & 38.4 \\
\hline & Postgraduate & 41 & 26.8 & 75 & 49.0 & 54 & 35.3 & 17 & 11.1 & 43 & 28.1 & 230 & 30.1 \\
\hline Employment & Self & 51 & 33.3 & 87 & 56.9 & 113 & 73.9 & 98 & 64.1 & 117 & 76.5 & 466 & 60.9 \\
\hline \multirow[t]{3}{*}{ Status } & Government & 93 & 60.8 & 52 & 34.0 & 36 & 23.5 & 43 & 28.1 & 32 & 20.9 & 256 & 33.5 \\
\hline & Unemployed & 09 & 05.9 & 14 & 09.1 & 04 & 02.6 & 12 & 07.8 & 04 & 02.6 & 43 & 05.6 \\
\hline & Total & & 100 & & 100 & & 100 & & 100 & & 100 & & \\
\hline
\end{tabular}

Source: Field Survey 2017 
This study examined length of stay in city and the results were presented in Table 2. Findings revealed most respondents $310(40.5 \%)$ have been living in city for more than 10 years, while about $9 \%$ of sampled population has been in city for just less than one year. Interestingly, length of stay in city does not guarantee dwellers satisfaction as respondents who have being residing in cities for less than 6 years feel satisfied than those that have being in city for more than 10 years.

TABLE 2. Length of stay in city

\begin{tabular}{lccccccccccccc}
\hline \multirow{2}{*}{ Length of Stay } & \multicolumn{3}{c}{ Abuja } & \multicolumn{2}{c}{ Benin } & \multicolumn{2}{c}{ Lagos } & \multicolumn{2}{c}{ Kano } & \multicolumn{2}{c}{ Onitsha } & \multicolumn{2}{c}{ Total } \\
\cline { 2 - 14 } & $\mathrm{N}$ & $\%$ & $\mathrm{~N}$ & $\%$ & $\mathrm{~N}$ & $\%$ & $\mathrm{~N}$ & $\%$ & $\mathrm{~N}$ & $\%$ & $\mathrm{~N}$ & $\%$ \\
\hline Less than one year & 17 & 11.1 & 05 & 3.3 & 12 & 07.8 & 28 & 18.3 & 09 & 05.9 & 71 & 09.3 \\
1 yr-5 yrs & 42 & 27.4 & 39 & 25.5 & 19 & 12.4 & 47 & 30.7 & 28 & 18.3 & 175 & 22.9 \\
5 yrs-10 yrs & 61 & 39.9 & 51 & 33.3 & 37 & 24.2 & 23 & 15.0 & 37 & 24.2 & 209 & 27.3 \\
Above 10 yrs & 33 & 21.6 & 58 & 37.9 & 85 & 55.6 & 55 & 36.0 & 79 & 51.6 & 310 & 40.5 \\
Total & & 100 & & 100 & & 100 & & 100 & & 100 & 765 & 100 \\
\hline
\end{tabular}

Source: Field Survey 2017

Studies reported that cities are places of opportunities for all categories of people (Floater et al. 2014; Watson, 2009). This study therefore investigated reasons why people reside in cities. As revealed in Table 3, employment was the major attraction for residents as claimed by $345(45 \%)$ of respondents. Unfortunately, employment opportunities in the selected cities is drastically low in recent time as unemployment and underemployment are dishearten issues in many Nigerian cities, and in spite of the prominence attached to the creation of more jobs by government at all levels and economic enhancement programmes for city dwellers, unemployment and underemployment appears to become chronic and intractable; which consequently results to poor standard of living and poverty among city residents. Next to this is marital factor (marriage) accounting for 29.3\% while access to education was the reason for $84(10.9 \%)$ of respondents. There are other factors adduced for residing in cities by residents, these are socialization (5.6\%), access to information $(3.8 \%)$, religious/spiritual upliftment $(1.8 \%)$, and pleasure $(0.3 \%)$.

TABLE 3. Reasons for residing in city

\begin{tabular}{|c|c|c|c|c|c|c|c|c|c|c|c|c|}
\hline Reasons & \multicolumn{2}{|c|}{ Abuja } & \multicolumn{2}{|c|}{ Benin } & \multicolumn{2}{|c|}{ Lagos } & \multicolumn{2}{|c|}{ Kano } & \multicolumn{2}{|c|}{ Onitsha } & \multicolumn{2}{|c|}{ Total } \\
\hline Employment & 86 & 56.2 & 65 & 42.5 & 31 & 20.3 & 65 & 42.5 & 98 & 64.1 & 345 & 45.1 \\
\hline Access to Education & 09 & 05.9 & 32 & 20.9 & 24 & 15.7 & 13 & 08.5 & 06 & 03.9 & 84 & 10.9 \\
\hline $\begin{array}{l}\text { Religion/spiritual } \\
\text { Upliftment }\end{array}$ & - & - & 03 & 01.9 & 09 & 05.9 & 02 & 01.3 & - & - & 14 & 01.8 \\
\hline Pleasure & 02 & 01.3 & - & - & - & - & - & - & - & - & 02 & 00.3 \\
\hline Personal & - & - & - & - & - & - & - & - & - & - & - & - \\
\hline Socialization & - & - & 16 & 10.5 & 27 & 17.6 & - & - & - & - & 43 & 05.6 \\
\hline Total & & 100 & & 100 & & 100 & & 100 & & 100 & 765 & 100 \\
\hline
\end{tabular}

Source: Field Survey 2017

Based on the premise that population in selected cities continues to increase despite inability of these cities to fulfill the needs of dwellers, it was reported that 465 (48\%) city dwellers are not satisfied living in the city (Table 4). Meanwhile, level of satisfaction in this study is related to availability, accessibility and efficiency of necessary facilities and services that can enhance quality of life.
Thus, assessment of these facilities (Table 5) shows a displeasing condition. For instance, electricity/power supply and transportation services were rated poor, while waste management, security and water supply were rated very poor. Interestingly, telecommunication services were rated to be good among other city services. This finding corroborates the position of Sommers (2010) that 'life in town is tough and sometimes threatening.' Similarly, results from this study 
TABLE 4. Rating of satisfaction with cities

\begin{tabular}{lccccccccccccc}
\hline & \multicolumn{3}{c}{ Abuja } & \multicolumn{2}{c}{ Benin } & \multicolumn{2}{c}{ Lagos } & \multicolumn{2}{c}{ Kano } & \multicolumn{2}{c}{ Onitsha } \\
\cline { 2 - 12 } Rating of Satisfaction & $\mathrm{N}$ & $\%$ & $\mathrm{~N}$ & $\%$ & $\mathrm{~N}$ & $\%$ & $\mathrm{~N}$ & $\%$ & $\mathrm{~N}$ & $\%$ & $\mathrm{~N}$ & $\%$ \\
\hline Highly satisfied & 43 & 28.1 & 45 & 29.4 & 21 & 13.7 & 37 & 24.2 & 23 & 15.0 & 169 & 22.0 \\
Satisfied & 33 & 21.6 & 13 & 08.5 & 17 & 11.1 & 24 & 15.7 & 14 & 09.1 & 101 & 13.2 \\
Fairly satisfied & 09 & 05.9 & 26 & 17.0 & 38 & 24.8 & 11 & 07.2 & 31 & 20.3 & 115 & 15.0 \\
Highly unsatisfied & 21 & 13.7 & 39 & 25.5 & 62 & 40.5 & 43 & 28.1 & 68 & 44.4 & 233 & 30.5 \\
Unsatisfied & 47 & 30.7 & 30 & 19.6 & 12 & 08.0 & 27 & 17.6 & 16 & 10.5 & 132 & 17.3 \\
Neutral/No response & - & - & - & - & 03 & 01.9 & 11 & 07.2 & 01 & 00.7 & 15 & 02.0 \\
Total & & 100 & & 100 & & 100 & & 100 & & 100 & \\
\hline
\end{tabular}

Source: Field Survey 2017

affirmed the perception of Simone (2004) about African cities. It was noted that most cities in Africa "don't work" and "life is reduced to a state of emergency" for most city dwellers. Displeasing state of facilities in selected cities, have resultant effects on the wellbeing of city dwellers. In Lagos, for instance, it was reported that people rely most on water vendors for water supply.

Most residents reported that they do not have access to adequate government pipe-borne water supply. This compel most respondents, particularly the high income earners to construct boreholes and wells, purchase different water storage tanks, while the low-income earners buy water from water vendors. Apart from the extra cost incurred, it is instructive to note that, lack of reliable and treated water supply from the government was reported to expose city dwellers to different water-borne diseases. In other words, the quality and quantity of infrastructural components is one of the indices used to examine the level of people's satisfaction with cities. This was based on the fact that infrastructure is the bedrock of cities economy on which other economic activities depend (Oluba 2008). Challenges of inadequacy of infrastructure and services in selected cities, and the country at large are all-pervading and difficulties experienced by cities dwellers are not only real, but growing in complexity daily.

Similar to the state of water supply is the ugly situation of transportation system reported by respondents. It is imperative to note that, effective planning, design and management of transportation system is one of the viable avenues of harnessing the advantages of cities, such as maximizing access to people and facilities. Responses from respondents justify this assertion. The poor state of intra-city roads, prolong waiting hours for public transport, traffic congestion and pollution, long walking distance were reported to impact negatively on quality of life (Dawood \& Rahmat 2015; Ismail \& Hashim 2015). The situation in the Federal Capital Territory-Abuja was observed to be fair compared with other selected cities. The Bus Rapid Transit system in the commercial nerve centre of the nation - Lagos was reported to assist respondents in reducing the travel challenge in terms of travel time and cost. Meanwhile, congestion and traffic induced pollution was reported to be high. It can be deduced based on the findings that there is need to urgently redress the situation of most services in the selected cities. It is shocking to note that the poor state of infrastructure, particularly electricity or power supply also affects the federal capital territory-Abuja.

It is worrisome that despite the challenges in cities, most respondents reported that lack of alternatives compels them to stay in cities. However, respondents adopt different coping strategies that include: use of power generating set, solar energy, combination of trips, cancellation of trips, construction of personal boreholes and wells, patronize waste management companies.

TABLE 5. Assessment of challenges of cities

\begin{tabular}{lllllllll}
\hline \multicolumn{1}{c}{ Factors } & $\begin{array}{c}\text { Electricity } \\
\text { Supply }\end{array}$ & Transport & Recreation & Security & Health & Telecom. & $\begin{array}{c}\text { Waste } \\
\text { Management }\end{array}$ & $\begin{array}{c}\text { Water } \\
\text { Supply }\end{array}$ \\
\hline Very Good & $49(06.4)$ & $92(12.0)$ & $191(25.0)$ & $12(01.6)$ & $39(05.1)$ & $267(34.9)$ & $43(05.6)$ & $22(02.8)$ \\
Good & $31(04.1)$ & $46(06.0)$ & $235(30.7)$ & $31(04.1)$ & $26(03.4)$ & $293(38.3)$ & $28(03.7)$ & $43(05.6)$ \\
Fair & $278(36.3)$ & $183(24.0)$ & $127(16.6)$ & $53(06.9)$ & $159(20.8)$ & $161(21.0)$ & $05(00.7)$ & $109(14.2)$ \\
Poor & $243(31.8)$ & $271(35.4)$ & $138(18.0)$ & $215(28.1)$ & $361(47.2)$ & $28(03.7)$ & $352(46.0)$ & $317(41.4)$ \\
Very poor & $145(18.9)$ & $173(22.6)$ & $74(09.7)$ & $437(57.1)$ & $149(19.4)$ & $16(02.1)$ & $337(44.0)$ & $274(36.0)$ \\
No response & $19(02.5)$ & - & - & $17(02.2)$ & $31(04.1)$ & - & - & \\
\hline
\end{tabular}

Source: Field Survey 2017 
Based on responses to availability and use of facilities in cities, empirical analyses (chi-square analysis) of cities satisfaction differentiation reveal that there is no significant difference in cities satisfaction. For instance, The result of the chi-square analysis shows that calculated chi-square values for selected variables - electricity supply [7.314]; transport [9.737] recreation [12.024]; health [9.737]; telecommunication [21.291]; waste management [18.604] and water supply [23.988] of cities satisfaction are less than the table value (31.41) at 0.05 Alpha Level. Based on the foregoing, it can be concluded that there is no significant difference in the level of residents' satisfaction in cities. This therefore implies that the situation of power supply; transport; recreation; telecommunication; health, waste management and water supply in selected Nigerian cities does not differ.

TABLE 6. Chi-square tests statistics

\begin{tabular}{|c|c|c|c|c|c|c|c|}
\hline & $\begin{array}{c}\text { Electricity } \\
\text { Supply }\end{array}$ & Transport & Recreation & Health & Telecom. & $\begin{array}{c}\text { Waste } \\
\text { Management }\end{array}$ & $\begin{array}{l}\text { Water } \\
\text { Supply }\end{array}$ \\
\hline Pearson Chi-Square & $7.314^{\mathrm{a}}$ & $9.737^{\mathrm{a}}$ & $12.024^{\mathrm{a}}$ & $9.737^{\mathrm{a}}$ & $21.291^{\mathrm{a}}$ & $18.604^{\mathrm{a}}$ & $23.988^{a}$ \\
\hline Df & 20 & 20 & 20 & 20 & 20 & 20 & 20 \\
\hline Asymp. Sig. (2-sided) & .213 & .973 & .915 & .973 & .380 & .548 & .243 \\
\hline $\mathrm{N}$ of Valid Cases & 765 & 765 & 765 & 765 & 765 & 765 & 765 \\
\hline
\end{tabular}

Source: Field Survey 2017

This study investigated the notable areas that can enhance quality of life and simultaneously improve level of satisfaction. The factor analytical technique was adopted towards identifying most important issue concerning improvement of dwellers satisfaction with city. The value of factors (loadings) shows the level of importance of factor concern. As revealed in Table 6, the most determinant factor for improving city satisfaction is improve power/electricity supply, followed by increase job/employment opportunity, transport infrastructure and food security. The lowest loading factor was the enforcement of planning and development regulations. The gross unsatisfaction of city dwellers, particularly in the selected cities is linked to inadequacy of city infrastructure and services. This affirmed the assertion of (Adenikinju 2003; Lee \& Anas 1992) that poor state of infrastructure and service is a major constraint to national and individual economic development.

TABLE 7. Factor loading of variables towards improved city satisfaction

\begin{tabular}{lc}
\multicolumn{1}{c}{ Variables } & Loading \\
\hline Improve Power/Electricity Supply & 1.003 \\
Increase job/Employment Opportunities & .985 \\
Improve transport infrastructure/system & .981 \\
Ensure food security & .971 \\
Improve Quality of Education & .942 \\
Affordable Housing & .875 \\
Improve information and Communication & .742 \\
Good Health/medical services & .715 \\
Increase number and quality of security personnel & .713 \\
Improve waste management services & .667 \\
Good banking and finance services & .633 \\
Good drainage system & .625 \\
Attractive city landscaping/green environment & .607 \\
Integrate E-governance & .557 \\
Reduced/eliminate ethnic conflicts & .514 \\
Reduced all types of pollution & .497 \\
Formalize informality & .401 \\
Improve quality and number of recreation centres & .398 \\
Encourage Citizen participation decisions/responsive governance & .361 \\
Enforcement of planning and development regulations & .355 \\
\hline Sourc: Field
\end{tabular}

Source: Field Survey 2017 


\section{CONCLUSION}

This study posits the fact that cities play increasing roles in infrastructural, economic change, poverty reduction and environmental development. Interestingly, position of cities in the global economy varies as their window of opportunities for development. Findings from this study reveal that infrastructural development remains the life-wire of activity system of cities. Thus, adequate infrastructure and efficient city management help to broaden the perspective of city dwellers and foreign investors; it enhances quality of life of individual as well as the city as a whole. The paper corroborates earlier studies that, improved city infrastructure as well as effective delivery of public services is a necessary element in liberating people from shackle of poverty.

Indeed, improved accessibility to employment, education, health, and other public services is also important for the welfare of the people and city system. More importantly, this study examined cities satisfaction within the contemporary urban development and management of Nigerian cities. Results have shown that infrastructure is pertinent for development, functionality and prosperity of cities. Adequate infrastructure in terms of improved water and sanitation, reliable power supply, efficient transport networks and modern information and communication technologies (ICTs) are factors noted in the paper that can enhance sustainability and economic growth of cities. It facilitate competitiveness of productive activities, foster labour performances, provides friendly environment investment in city.

The major policy implication for future development of Nigerian cities derivable from above findings falls within the realm of governance. Furthermore, empirical analyses reveal the need for effective governance capable of providing and managing basic facilities that will drive cities economies and improve lives of citizens. Findings suggest that policy makers need to ensure implementation of appropriate policies, particularly facilitating citizen participation in developmental affairs and maintenance of transparent governance infrastructure. It was further noted that qualified professionals should be afford the opportunity to devise appropriate action plans, implementation and monitoring systems.

\section{REFERENCES}

Adeagbo, A. 2002. Ajoda new town: an appraisal of its implementation. Nigerian Institute of Social and Economic Research (NISER).

Adenikinju, A. 2003. Electric infrastructure failures in nigeria: a survey-based analysis of the costs and adjustment responses. Energy Policy 31: 1519-1530.

Agbola, T. \& Agunbiade, E. 2007. Urbanization, slum development and security of tenure: the challenges of meeting Millennium Development Goal (MDG 7) in Metropolitan Lagos, Nigeria. PRIPODE (Programme for International Research on the Interations between Population, Development and Environment Workshop) 2007, Session; 1 .
Ariyo, A. \& Jerome, A. 2004. Utility privatization and the poor: Nigeria in focus. Heinrich Boll Foundation.

Banister, D. \& Bowling, A. 2004. Quality of life for the elderly: the transport dimension. Transport Policy 11: 105-115.

Cohen, B. 2004. Urban growth in developing countries: a review of current trends and caution regarding existing forecasts. World Development 32(1): 23-51.

Coker, A.O., Awokola, O.S., Olomolaiye, P.O. \& Booth, C.A. 2007. Challenges of urban housing quality and its associations with neighbourhood environments: Insights and experiences of Ibadan city, Nigeria. Journal of Environmental Health Research 7(1): 1-9.

Dawood, S.A. \& Rahmat, R.A. 2015. Factors that affect cycling transport mode for postgraduate students at Universiti Kebangsan Malaysia by logit methods. Jurnal Kejuruteraan 27: 1-7.

Egunjobi, L. 1999. Our Gasping Cities. An Inaugural Lecture University of Ibadan, 21 October.

Engelke, P. 2012. The security of cities: development, environment, and conflict on an urbanizing planet. Stimson Press.

Floater, G., Rode, P., Robert, A., Kennedy, C., Hoornweg, D., Slavcheva, R. \& Godfrey, N. 2014. Cities and the new climate economy: the transformative role of global urban growth. Technical report on new climate economy cities; Paper 01. LSE Cities, London School of Economics and Political Science.

Glaeser, E. 2011. Triumph of the city: how our greatest invention makes us richer, smarter, greener, healthier, and happier. Penguin Books.

Ismail, A. \& Hashim, H.F. 2015. Modelling of transportation policies to encourage shifting from private car to the public transport usage in Putrajaya. Jurnal Kejuruteraan 27: 15-21.

Lee, K.S. \& Anas, A. 1992. Impacts of infrastructure deficiencies on nigerian manufacturing: private alternatives and policy options. Infrastructure and urban development department report. No. 98. World Bank, Infrastructure and Urban Development Department.

McKinsey Global Institute. 2010. India's urban awakening. building inclusive cities, sustaining economic growth. McKinsey and Company.

National Population Commission (NPC). 2010. Population distribution by sex, state, $L G$ and senatorial district: Federal Republic of Nigeria 2006 population and housing census. National Population Commission.

Odufuwa, B., Fransen, J., Bongwa, A. \& Gianoli, A. 2009. Cities, theories and reality. Journal of Geography and Regional Planning 2(10): 243-248.

Oluba, M. 2008. Who should provide public infrastructure in Nigeria?. Economic Reflections B(4): 1-7.

Onibokun, A. 1992. The crisis in urban management in Nigeria in the nineties: problems and opportunities. NITP (Nigeria Institute of Town Planners $23^{\text {rd }}$ annual conferences) 1992, Proceeding; 2-12. 
Oyesiku, O.O. 1998. Urbanization and urban management crisis in nigerian cities: the ethnic violence and conflict dimensions. African Urban and Regional Studies 1(1): $1-11$.

Oyesiku, O.O. 2010. New cities in urban and regional development planning. Longman.

Rosenthal, S. S. \& Strange W. C. 2003. Geography, industrial organization, and agglomeration. Review of Economics and Statistics 85(2): 377-393.

Simone, A. 2004. For the city yet to come: changing African life in four cities. Duke University Press.

Sommers, M. 2010. Urban youth in Africa. Environment and Urbanization 22(2): 317-332.

United Nations Development Programme (UNDP). 1996. Human development reports. Oxford University Press.

United Nations Human Settlements Programme (UNHABITAT). 2012. State of the World's Cities 2012/2013: Prosperity of Cities. United Nations Human Settlements Programme (UN-HABITAT).

Watson, V. 2009. The planned city sweeps the poor away: urban planning and 21 st century urbanisation. Progress in Planning 72: 151-193.
World Bank. 1995. Restoring urban Nigeria: a strategy of restoring urban infrastructure and services in Nigeria. World Bank.

*Bashir Olufemi Odufuwa

Nathaniel Oluwaseun Ogunseya

Umar Obafemi Salisu

Simeon Oluwagbenga Fasina

Department of Urban and Regional Planning

Faculty of Environmental Studies

College of Engineering and Environmental Studies

Olabisi Onabanjo University

Ago-Iwoye, Ogun State- Nigeria.

*Corresponding author; email: odufuwabashir@yahoo.com

Received date: $27^{\text {th }}$ January 2018

Accepted date: $20^{\text {th }}$ April 2018

Online First date: $1^{\text {st }}$ September 2018

Published date: $31^{\text {st }}$ October 2018 